\title{
CONFERÊNCIA
}

\section{ASPECTO ATUAL DOS GRANDES PROBLEMAS DA HISTÓRIA DE ROMA (1)}

Qual é o primeiro romano que conhecemos? Dêle só possuimos o crânio; êste foi encontrado em 1939, em Saccopastore, a três quilômetros da Porta Pia, na margem esquerda do Ãnio; era um homem do tipo Neanderthal; mais ou menos contemporâneo do. elephas antiquus, cujo esqueleto foi descoberto durante os trabalhos que revolveram os foruns imperiais, para a abertura da Via dell'Impero. Sem dúvida êle conheceu também o hipopótamo e o rinoceronte. Esse Homem de Neanderthal é o representante de uma raça humana muito primitiva, com suas órbitas sálientes, com seu queixo brutal. É uma raça encontrada através de tôda a Europa e que desapareceu por ocasiāo da última época glacial. Ele vivia há uma quinzená mais ou menos de milênios. Ulm crânio muito semelhante a êsse foi encontrado no extremo sul do Lácio, no Monte Circei.

Infelizmente, após essa curiosa visāo, nāo se pode acompanhar, nem mesmo de milênio em milênio, os progressos do povoamento. Longos periodos da vida do Lácio sāo completamente vazios. Após o espantoso prólogo neandertalense, nāo cremos que possamos ter algum habitante dessa regiāo antes do início da idade do cobre. É possivel mesmo que as erupções vulcânicas dos Montes Albanos tenham impedido as instalações humanas na planície latina até a idade do bronze. Pensamos que se deveria encontrar os estabelecimentos primitivos que precederam a chegada de Rômulo, e sobretudo êsse estabelecimento muito antigo, sôbre o AvenLino ou, mais certamente ainda, no sul do Aventino, ao qual se dava o nome de Remúria, a cidade de Remo. Porque o conflito de Rômulo e Remo é, provàvelmente, o arranjo lendário da batalha entre o bando de Rômulo e um velho estabelecimento indígena, anterior à própria chegada dos pastores. Como se desejaria encontrar o sítio dessa aldeia pré-histórica mais velha do que Roma...

(1). - Conferências pronunciadas na Faculdade de Filosofia, Ciencias e Letras da Universldade de Så Paulo nos dias 23 e 24 de outubro de 1900. Texto francés revisto pelo autor e traduzido pelo licenclado Moisés Rovner. 
Para nós, como para os próprios romanos, é no meado do VIII século que Roma nasceu. Acabamos de ter a maravilhosa surpresa de encontrar o que resta das casas dos fundadores de Roma.

Detenhamo-nos nesse canto do Monte Palatino que domina o antigo mercado dos bois, o Forum Boarium; essa parte da colina chamava-se o Germal; foi aí, no cume da escada de Caco, que Rômulo fundou sua cidade.

As escavações feitas nesse local por Dante Vaglieri em 1906 tinham reconhecido traços de retoques na rocha de tufo horizontal que estava atravessada por furos; lembramo-nos de que Vaglieri nos disse entāo que aparentemente êsses orifícios indicavam o fundo de sepulturas em forma de poço, que teriam sido escavadas, e êle nos mostrava fragmentos de cacos idênticos aos que se encontram no cemitério arcaico do Forum; as escavações foram recomeçadas por P. Romanelli em 1949; elas reconheceram o sitio de cabanas de plano grosseiramente quadrangular; um rêgo profundo as cerca, para o escoamento das águas. Os orifícios observados por Vaglieri correspondem na realidade ao local de estacas de madeira que sustentavam os muros de tijolos crus.

Eis, portanto, o local exato onde Rômulo fixou êsse bando de pastores semi-salteadores do qual êle era o chefe; as sepulturas dessa população sāo talvez as que Boné descobriu em 1899 em pleno Forum.

De acôrdo com a tradiçāo antiga, estamos no meado do VIII século antes da nossa éra. Quase ao mesmo tempo aparecem os primeiros vasos gregos importados; já a povoação atraía um certo comércio. Sua riqueza era sòmente de bois e de carneiros, e o Palatino devia transformar-se à noite num estábulo. Uma das portas antigas, a porta Mugônia, recebeu êsse nome dos mugidos dos bois, que, à noite, voltavam para o estábulo.

Mas êsse bando de pastores, de onde vinha? E necessário que se diga que somos obrigados a interrogar a história dos túmulos. Um problema muito grave continua a dividir os especialistas. No cemitério dos foruns romanos, encontram-se, mais ou menos contemporâneos, túmulos de inumaçāo, e outros de incineraçāo. A diferença dos ritos funerários tem uma significaçāo profunda? Da nossa parte, persistimos em pensar que a marcha dos povos incinerantes através da Europa deve permitir-nos balizar a rota dos indo-europeus, queremos dizer das tribos que trouxeram e divulgaram as linguas indo-européias, às quais pertencem as nossas.

Esse problema da origem dos indo-europeus está no primeiro plano das preocupações de nossa ciência; queremos sobretudo saber se êles possuiam um tipo particular de economia, de religiāo, de estrutura social; por exemplo, Dumézil pensa ter demonstrado, por pacientes trabalhos de comparaçāo lingüística, que os indo- 
-europeus possuiam uma sociedade tripartite: uma casta de guerreiros, uma de padres, uma de camponeses agricultores e operários. Ele pensa que a Roma primitiva conheceu essas três castas que corresponderiam às tribos originais de que temos os nomes: a trinclade dos grandes deuses romanos, Júpiter, Marte, Quirino, atestaria de maneira evidente a trissecção primitiva: Júpiter, deus dos padres, Marte, deus dos guerreiros, Quirino, deus dos obreiros camponeses; mas que vale essa tese tão interessante? Incorremos na vindita do autor por termos afirmado que nāo percebíamos nos textos latinos absolutamente nada daquilo que êle via; nāo existe nenhum traço histórico de uma trissecção dos povos latinos em caștas. Mas enfim, um grande problema se apresenta, e era nosso dever assinalá-lo.

Nào é sòmente a aldeola de Rômulo, é tôda a Roma dos Reis que pouco a pouco surge aos nossos olhos. Era muito tentador, para os historiadores críticos, colocá-la no mundo da lenda. Todavia, Camille Jullian, numa dessas notas febris que publicava na Revue des Etudes anciennes, colocou um dia a Roma dos Tarquínios entre os grandes centros mercantes do VI século, como $\mathrm{Mi}$ leto, Síbaris e Marselha. Ora, possuimos agora milhares de fragmentos de vasos gregos que provém do solo de Roma. Examinemos sobretudo as descobertas que se fizeram escavando-se, ao pé do Capitólio, no mercado dos bois, as ruínas de dois templos arcaicos: ai encontramos uma quantidade surpreendente de vasos áticos - êsses templos erain sem dúvida os-templos geminados da Fortuna e da Māe, cuja fundaçāo a tradiçāo atribuia a Sérvio Túlio. $\dot{E}$ o tempo em que Pisistrato governava Atenas, o primeiro século de expansão dos vasos áticos e das moedas com a marca da coruja. Nenhuma moeda foi encontrada em Roma: mas de onde vinham todos êsses vasos? A tradição diz que Óstia foi fundada no tempo dos Reis, mas até o presente nada a confirma. Parece, pois, provável que êsses vasos tenham vindo pelo pôrto etrusco de Cere; os etruscos estendiam então seu império até a Campânia; entre a Toscana e a Campânia, Roma foi sempre a preciosa presilha que ligava as duas jóias.

Rômulo, parà atrair habitantes para. sua nova cidade, abriu no Capitólio um local de asilo, ao pé do santuário de um Júpiter infernal, Veiovis. O templo foi agora encontrado, com um fragmento da estátua do deus, mas trata-se de uma restauração do fim da República.

Entre as duas guerras, tinham-se reconhecido os alicerces do Capitólio; mais recentemente, reconheceu-se a própria avenida pela qual os triunfadores subiam ao santuário.

O problema da topografia primitiva de Roma, a nosso ver, só será plenamente resolvido no dia em que se tiver encontrado de novo o templo de Jano Quirino. Sem dúvida, era uma porta da cérca primitiva aquela pela qual partiam os guerreiros, e e por isso 
que ela era fechada em tempo de paz. Pensamos ter encontrado no Forum o local em que se cruzavam as duas linhas perpendiculares, uma das quais era orientada de norte a sul, e a outra, de oeste a leste, que os etruscos traçaram quando Roma foi novamente fundada por influência dêles. Uma dessas linhas é a Via Sacra, que passa entre a casa do Rei e o Templo das Vestais; esta construçāo do espírito apenas será certa no dia em que soubermos que ela é confirmada pelo próprio sitio de Jano. Mas é um desastre, e nós o lamentamos, o fato de as escavações da Via dell'Impero nāo terem reconhecido o templo de Jano, que está certamente muito perto delas; é uma lacuna muito grave.

Diz a tradiçāo que a Roma dos Tarquínios era circundada por uma grande muralha e cobria imenso espaço; quase nāo se acreditava mais na existência dêsse muro, chamado de Sérvio Túlio, porque os principais fragmentos da muralha que se conservou são evidentemente posteriores à invasāo gaulesa. Observava-se, todavia, com curiosidade, que um pequeno muro de pedras menores $e$ muito bem feitas era, em muitos lugares, paralelo à grande muralha. Ora, está provado agora que êste pequeno muro é anterior ao muro do IV século e que, ao que tudo indica, êle remonta ao tempo dos Reis; Roma atingira desde êsse tempo a extensāo que recuperou sòmente dois séculos mais tarde, após longa crise. Está mesmo provado, o que nāo era de esperar-se, que o muro dos Reis cercava o monte Aventino, que, entretanto, era considerado como exterior aos limites religiosos da cidade, que se chamava o pomoerium.

Finalmente, conforme a tradiçāo, é ao segundo Tarquinio que caberia o mérito de haver iniciado a construção do templo do Capitólio; o frontão era adornado de estátuas de terracota para as quais se havia invocado Vulca de Veii. Não encontramos as estátuas de novo, mas conhecemos atualmente o escultor, pois sòmente a êle podem atribuir-se obras admiráveis que foram encon1:adas en Veii, um Apolo e um Hércules que disputam a posse de uma corça. O estilo é o das Jovens da Acrópole que eram chamadas Korai e iguala-as em perfeição. Fragmentos novos dêsse grupo acabam de ser encontrados. As estátuas eram colocadas distäntes umas das outras, nos ângulos do telhado.

Seja-nos permitido observar qual foi a participaçāo da escola francesa de Roma nesta obra de ressurreiçāo. Foi a um jovem céramólogo francês que os sábios italianos confiaram o cuidado de classificar os cacos gregos encontrados em Roma; a cronologia rigorosa por êle estabelecida será a base da cronologia da Roma dos Reis. Foi um de nossos discípulos que, observando no Aventino que a muralha do IV século estava superposta ao muro de pedras menores, chamadas de capellacio, pôde demonstrar que êsse muro era o da Roma dos Reis. Outro nosso aluno teve a sorte, que invejamos, de fazer sondagens no local que se presumia ser o do 
tcmplo de Jano. Verificamos recentemente que êle localizara bem sua pesquisa, mas que lhe foi impossivel atingir as camadas profundas. E foi ainda um dos nossos alunos que, escavando na Etrúria perto de Bolaena, soube distinguir uma vasta muralha desconhecida, que só pode ser a de Volsinii, capital da liga etrusca, cuja exata localizaçāo continuava sendo objeto de infindáveis controvérsias.

$\hat{E}$ verdadeiramente admirável que êste local de Roma, retocado por tantos trabalhos gigantescos, tenha conservado para nós o testemunho da Roma real. Nāo é inútil saber que uma delicada civilizaçāo brilhava em Roma no VI século; Roma participou, portanto, dêsse maravilhoso progresso que renovou entāo as correntes de pensamento na Eurásia. Porque êste século é aquêle em que, ao que parece, Confúcio ensinava na China e Buda na India, Zoroastro no Turquestāo, Orfeu na Trácia,. Pitágoras na Itália; é o tempo em que os tiranos destruiam os privilégios das aristocracias, pois foi certamente essa a significaçāo dos governos de Pisistrato em Atenas, Periandro em Corinto, Policrates em Samos e Tarquínio em Roma.

O VI século viu o apogeu dos etruscos; o enigma dêsse povo nāo está resolvido; dêle possuimos umá dezena de milhares de inscrições que, para dizer-se a verdade, sāo quase tôdas funerárias, estando sua, decifraçāo apenas esboçada. As hipóteses mais contraditórias sôbre a origem dos etruscos conservam seus partidários: são indígenas italianos, segundo Schuchardt ou Pallottino, invasores vindos pelos Alpes, segundo Helbig, imigrantes oriundos da Ásia Ménor, segundo Ducati, em conformidade com a trađiçāo de Heródoto. Chegaram à Itália ao tempo da guerra de - Tróia, isto é, pelo século XIII antes da éra cristā, conforme estudo bem recente de Jean Bérard. Nāo chegaram muito antes do ano 700, na opiniäo de Ducati, que, assim, concorda com uma tese que apresentamos muito antes dêle.

Consideramos como certo serem os etruscos um povo misto; encontram-se entre êles grupos cujas tumbas em forma de urnas- cabanas são idênticas às dos latinos; reconhece-se na Toscana a penetração de tribos vindas da Grécia, que desembarcaram na costa adriática; ai se reconheceriam mesmo verdadeiras colônias gregas, como em Pisa, mas isso nāo é o essencial. A unidade do povo etrusco deve-se à chegada de imigrantes orientais oriundos da Ásia Menor, provàvelmente da Cilicia. Mostramos recentemente que os livros etruscos, dos quais nos foi conservado um exemplar, deviam ser do tipo babilônico. Eis como fizemos essa demonstração: um calendário para se interpretar o trovão nos foi conservado sob o nome de um contemporâneo de Cícero, o pitagórico Nigidio Figulo, que teria traduzido um documento etrusco; êsse texto foi sempre considerado muito suspeito. Ora, ao ribombar o trovăo perto de Roma, pouco depois de Cícero ter regressado do exilio, foram 
consultados os padres etruscos; temos o texto da resposta dêles, que, evidentemente, se inspira num calendário idêntico ao de $\mathrm{Ni}$ gídio. Esste é, pois, indiscutivelmente autêntico. Ora, êle mesmo é de tipo idêntico ao dos calendários encontrados em Ninive na biblioteca de Assonitanipal e que datam mais ou menos do VIII século. É quase necessário admitir que os etruscos trouxeram para a Itália lịvros do tipo babilônico.

Julgamos, aliás, que nāo há nada que prove a chegada dêsse povo oriental à Toscana antes de se avizinhar o ano 700 . A migração etrusca é contemporânea da das primeiras colônias gregas ou é mesmo pouco posterior a elas. Esta migração explica-se, aliás, sem dúvida, pelas terriveis devastações feitas nesse tempo na Ásia Menor pela invasāo dos cimérios, povo de origem asiática.

Se realmente um povo originário do Oriente trouxe para a Itália parcelas da civilização babilônica, devemos levar em conta êsse fator bem curioso da civilizaçāo chamada latina; de fato, bem sabemos que o fígado de bronze de Piacenza, destinado à instruçāo dos arúspices, é muito semelhante a figados encontrados entre os hititas e os babilônios. $E$ os demônios etruscos da Morte fazem lembrar os demônios babilônicos; os historiadores nāo determinaram ainda tôdas as conseqüências dessa longínqua influência da Babilônia sôbre os etruscos e, por intermédio dêstes, sôbre Roma.

A êsse periodo brilhante do VI século seguiu-se na Itália um declinio; vimos renascer a Roma dos Tarquínios, procuramos inùtilmente dissipar as nuvens que envolvem a história de Roma desde a queda dos Reis até à época que se seguiu imediatamente à invasão gaulesa. Os vestígios arqueológicos que se podem datar do $V$ século sāo tão raros em Roma, que, por vêzes, afirmou-se que as campas do $\mathrm{V}$ século nāo foram novamente encontradas. Estamos inclinados a crer que foram encontradas, mas que nāo se lhes pode atribuir datas, porque elas nāo encerram vasos gregos e porque os objetos que nelas se encontram nāo assinalam nenhum progresso técnico.

Constitui para nós grande surprêsa observar êste verdadeiro hiato entre o ano $470 \mathrm{e}$ o ano 360 mais ou menos. $\hat{E}$, todavia, a época em que a arte grega atinge o apogeu, o tempo em que foram construidos e decorados o templo de Zeus, em Olimpia, o Partenão, de Atenas, também o tempo dos admiráveis dramas dos grandes poetas trágicos e do delicioso Heródoto, que, a meu ver, forneceu aos historiadores de todos os tempoś um modêlo que êles esquecem em demasia. É também o tempo de Praxiteles, de Aristófanes e do homem cuja açāo sôbre o pensamento humano foi mais eficaz que a de qualquer deus: Platão. Êsse periodo parece ser, no Ocidente, estéril e morto. Convém observar que esta nota nāo se aplica ùnicamente a Roma, valendo, no Ocidente, para todo o mundó bárbaro. Ela se`verifica, na Gália, nas escavações da 
Provença, e só se pode explicar pela interrupçāo das relações comerciais entre o leste e o oeste do Mediterrâneo. De fato, parece que assistimos em Roma a uma volta da barbárie. Tudo se passa como se Cartago e Corinto, donas dos estreitos da Sicilia, tivessem dificultado o comércio das cidades concorrentes e, especialmente, de Atenas. Dêsse modo se explicaria a guerra do Peloponeso, que constitui, principalmente, um esfôrço feito por Atenas para ter acesso aos mercados do Ocidente.

Esta aparente barbárie, porém, esconde um profundo trabalho interno em tôrno do qual começou a constituir-se em redor de Roma um Estado Camponês de todo diferente do tipo primitivo da Cidade. O porvir pertencia a êsses Estados camponeses semi-bárbaros, na Macedônia e em Roma.

Nāo insistiremos quanto a êste periodo, que é aquêle em que foi fundado o Tribunado da Peble, em que foram redigidas as XII Tábuas, o primeiro Código escrito de Roma. Ev evidente que a tradição histórica é enganadora e que a ausência de qualquer documento arqueológico, de qualquer inscrição, nada nos permite pôr em seu lugar. $\hat{E}$, por enquanto, uma lacuna muito grave.

O documento essencial que temos para a história dêsse periodo é a lista dos magistrados, dos cônsules, que chamamos os Fas- ' tns. Qual o valor dessa lista? Mommsen nela depositava incondicional confiança; a maioria dos sábios modernos segue-lhe o exemplo. Estamos convencidos, da nossa parte, de que assiste razão aos que a consideram uma falsificação tardia. Eram os Pontifices que mantinham em dia a crônica dos acontecimentos de Roma. Mas desde quando? Nāo antes de 296, na opiniāo de Jules Beloch. E preciso ir mais longe. É também por essa mesma data que foi redigida a primeira versão da história romana dos tempos mais remotos. É fácil dar a prova disso. Todos os magistrados de Roma, do fim do IV século, se atribuiram ilustres antepassados. Júnio Bruto atribuiu a un pseudo-ascendente a qualidade de primeiro cônsul de Roma. Ápio Cláudio, o grande cônsul de 312 , tornou-se chefe dos decênviros de 450. Após o ano de 296, porém, tudo muda: os novos cônsules, Fabriciano, Cúrio, Coruncânio, nāo puderam atribuir-se antepassados. Aparentemente, os Fastos haviam, desde essa época, tomado a sua forma quase que definitiva.

Nāo se pode exagerar a importância do trabalho realizado mais ou menos no ano 300 por êsses grandes homens, os primeiros remanos, cuja figura entrevemos, que são algo mais que nomes, Ápio Cláudio, que construiu a Via Ápia, Flávio, editor do cálendátio Ogúlnio, que, no dizer de Tito-Lívio, pôs os meninos sob os úberes da Lôba, Volúmnio, ésse grande etrusco de Perúgia, anigo de Ápio, que teve seu lugar entre os cônsules de Roma.

Flávio, editor do calendário. Possuimos a lista das grandes festas de Roma, lista que, desde Mommsen, é denominada calendário de Numa; acredita-se que êle seja anterior à fundação do 
Capitólio, porque nele nāo se encontram as festas de Júpiter; è empregado como precioso documento para a história do tempo dos Reis. $E$ isto constitui, a nosșo ver, grave êrro. As festas de Júpiter nāo estāo nele de todo ausentes: sāo as de todos.os idos, dias de plenilúnio, e sabemos que nesses dias, todos os meses, os siacerdotes subiam em procissāo ao Capitólio. Segundo diz expressàmente a tradição, foi Flávio quem redigiu o calendário. Bem mostra êle qual era, nessa data, a importância das festas agrárias: é a história da espiga de trigo que a série das mais ilustres festas conta.

Ogúlnio, que pôs os meninos sób os úberes da Lôba. Possuimos essa velha lôba; tem ainda, numa pata, o sinal do raio que a fustigou no ano 65 , anunciando o grande perigo que se preparava para o consulado de Cícero. Essa velha lôba é, provàvelmente, obra etrusca do ano 500 mais ou menos. Mas a lenda dos meninos Rômulo e Remo é mais tardia. Retenhamos a data de 297, em que os edis fizeram com que se fundisse o grupo dos meninos e o colocaram sob a lôba.

Foi também por êsse mesmo tempo que o nome de Roma se tornou famoso no mundo grego. Bem recentemente, disso encontramos um testemunho que muito impressionou os eruditos. Um papiro forneceu um fragmento do sumário de uma poesia de $\mathrm{Ca}$ limaco, escrita aparentemente em 260 mais ou menos: o poeta aí celebra o dito heróico de uma mulher romana; como seu filho, que um ferimento tornara coxo, evitasse aparecer em público, ela lhe disse que devia glorifirar-se com o seu defeito, considerando-o uma grande honra. Ora, îsse ferido de guerra nāo é senāo o cônsul de 293.

Foi em 273 que se concluiu a amizade entre Roma e o Egito. É grande êrro não se ver nesse fato mais do que uma cláusula de estilo. Um texto quase contemporâneo, de Licofronte - do qual um belo estudo de Picard acaba de determinar a data certa - diz que Roma e o Egito concluiram um acôrdo para dividirem entre si a cetro da terra e do mar; e acaba-se por se obter a prova de que o Egito teve, entāo, de concluir com Roma essa uniāo monetária que esta procurara até entāo com Tarento.

$O$ estudo das origens das civilizações clássicas muito deve às coijparações tiradas das sociedades selvagens. A obra de Frazer sōbre o Ramo de Ouro continua sendo para nós uma compilação muito preciosa. Mui recentemente, um sábio holandês, Wagenvoort, elucidou devidamente a noção do imperium romano, comparando-o com o mana das sociedades australianas. Melhor seria, a nosso ver, comparar a sociedade pastoral da primitiva Roma com uma sociedade selvagem de tipo puramente pastoril, tal como, por exemplo, a dos massai da África. Verificar-se-ia, de um lado e de outro, que a religiāo tende a um monoteísmo, que o regime da familia é patriarcal. 
Reclamamos, sobretudo, que se dê extrema importância ao papel da noção de fides, boa fé, no primitivo direito romano. Erramos ao dizer que êsse direito é inteiramente formalista e frio. $\mathrm{Na}$ realidade, nāo há em direito romano primitivo noçāo mais essencial do que essa de fides. O que diz o general romano vencedor a um povo vencido? Convida-o a confiar ná fides de Roma, a ter confiança em Roma, a entregar-se a ela, afiança-lhe que Roma só pensará no bem dè quem se entregar em suas mãos. Os modernos têm tanta dificuldade em imaginar tal modo de proceder, que, sem razão, contestam a narrativa formal que é feita da Entrega de Cápua às māos de Roma. É, entretanto, muito certo que as coisas se passaram dêsse modo. A fim de obter socôrro de Roma, a gente de Cápua nāo hesitou em entregar-se-lhe, pois depositava confiança na sua fides. Uma moeda de prata cunhada em Locros, em 276, durante a guerra de Pirro, representa Roma sentada diante de uma divindade denominada Pístis, isto é, Fides (confiança). Ainda mais tarde acontecia dizer Roma a um povo vencido: escolhei, quereis um tratado segundo as leis? Nāo preferis entregar-vos à nossa fides? A nosso ver, melhor seria que confiassem na fides de Roma. Nāo tardou, porém, o momento em que os romanos perderam o sentimento dos deveres morais que contraíam com os povos que confiavam na sua fides, e foi pelo abuso dessa palavra que trataram Cartago com atroz crueldade.

$\hat{E}$ essa noçāo fundamental, evidentemente, que explica a natureza do imperialismo romano, e Cícero tem tôda a razāo ao dizer que a dominação de Roma sôbre o mundo constitui antes uma proteçāo que um jugo.

Se, porém, a noçāo de fides explica a forma da política de Roma, parece certo que as noções profundas sāo ditadas pelo interêsse econômico. Nada é mais expressivo, por exemplo, do que - mapa da Nova Geografia universal que indica o traçado das vias romanas, que, na Itália Central, coincide exatamente com o dos percursos de transumância: é evidente que disso decorrem conclusões muito graves. Cabe a Albert Grenier o mérito de haver, pela primeira vez, demonstrado que a politica de Roma fôra, em sua origem, dominada pela necessidade de se garantir a liberdade das estradas de transumância; a nosso ver, porém, nāo the assistiu razāo ao julgar que essas preocupações deixaram, desde - V século, de influenciar a politica romana, porque a criação dos rebanhos transumantes se teria entāo interrompido, para continuar somente no tempo de Catão-o-Antigo. Parece-nos evidente que tal interrupção não se realizou. A história de Roma foi, até o III século, uma história de bois e de carneiros. Foram os carneiros que abriram caminho para os exércitos. E fácil ver que a mais antiga via romana, a via de Reate, na Sabinia, é uma estrada de transümância. Ora, a Reate iam, no verāo, rebanhos oriundos do tabuleiro da Apúlia. Foi seguindo êsses rebanhos que os romanos 
penetraram na Apúlia. A tradiçāo sabe perfeitamente que foi disfarçando-se em pastor que um Fábio, em 310, conseguiu penetrar no norte da Etrúria.

Karl Marx, em luminosa nota do Capital, diz que é a história da propriedade agrária que explica tôda a história de Roma. Tem razüo em acentuar a importância dos problemas agrários, nāo, potém, em desconhecer que muito cêdo entraram os interêsses dos capitalistas em conflito com os da classe agrária. Os belos estudos recentes sôbre a história da moeda romana permitem escrever páginas totalmente novas acêrca da história das finanças de Roma. Sabemos agora que cada uma das grandes guerras, desde o III século, foi seguida de uma crise monetária que provocou a inflação, acompanhada de desvalorizaçāo. Ao mesmo tempo, a conquista romana provocava, nos povos vencidos, catástrofes monetárias. O próprio denário de prata aparece cêrca de cem anos depois da data tradicional, apenas em 179, e assinala um momento de estabilizaçāo. Nāo terminaram, porém, ainda, as manipulações monetárias, que reaparecerăo quando a politica do partido popular fizer vultosas despesas. Pode-se acompanhar o conflito entre os agrários, partidários da inflaçāo, e os democratas, partidários da revalorizaçāo monetária.

Dêsse modo, tôda a história da segunda parte da República romana assume aspecto mais realista. Polibio notou, já, que, por volta do ano 150 , os romanos tinham o seu dinheiro colocado nas sociedades financeiras, que distribuiam espécies de ações, de obrigações; tôda Roma volvia os olhos para a cotaçāo da Bôlsa; Cícero descreveu de modo surpreendente a ruina financeira causada, em 88, pela guerra de Mitridates. Cabe, mesmo, perguntar se a vida econômica não foi, desde essa época, atravessada por crises de todo semelhantes às que, periòdicamente, abalam, entre nós, todo o edifício capitalista das sociedades modernas. $\hat{\mathrm{E}}$ impossivel nāo se reconhecer que, pelo ano 33 de nossa éra, no reinado de Tibério, a economia romana sofreu uma crise exatamente comparável aos fenômenos econômicos que denominamos: brusca restriçāo de crédito, falências; ela foi debelada por adiantamentos feitos pelo Estado. Ora, a crise que a República atravessa no tempo de Catilina é bem semelhante: os credores recusaram-se a renovar seus créditos, os que pediam dinheiro emprestado foram obrigados a fazer vendas forçadas; Cícero serviu-se do recurso típico dos Estados modernos em tais circunstâncias: a confiscação do ơuro. Mandou vigiar em todos os portas a partida dos navios, para certificar-se de que não levavam ouro. A moratória era a única soluçāo. Cícero, porém, era o defensor dos financistas e tomou a decisão mais maléfica de tôdas: obrigar os devedores a apressarem a venda dos seus bens, justamente no momento em que estavam desvalorizados. 
A história do comêço da república romana é uma história de bois e carneiros e ela é estudada examinando-se o percurso das estradas de transumância. A história do fim da república romana é a das sociedades financeiras que exploravam o mundo conquistado, e nāo a compreenderemos bem sem possuirmos as taxas da Bôlsa, que funcionava no Forum, bem perto do templo dos Castores.

Gostaríamos de narrar um episódio pouco conhecido da vida ccmercial da época; ninguém teve sua atençāo voltada para um dos descobrimentos mãis surpreendentes dêstes últimos meses. Um sábio francês trouxe de Oc-eo, perto de Saigon, uma coleçāo de sinetes inspirados pela arte helenística e romana, de cujo interêsse falaremos agora mesmo; notou êsse sábio que os indigenas usam atualmente adornos bárbaros feitos, se nāo nos enganamos, de espinhas de peixes. Ora, (e isto é admirável) no Museu do Palatino, em Roma, êle viu os mesmos adornos, disseram-lhe que foram encontrados debaixo da chamada casa dos grifos. Em junho último, estivemos em Roma, visitamos o Museu do Palatino, e o diretor, eminente sábio, nāo conhecia a observaçāo feita pelo francês. Examinando os mostruários, reconhecemos, efetivamente, êsses adornos bárbaros.

Que é, porém, a casa dos grifos? É uma casa republicana, construida na época do nascimento de Cícero; foi recoberta pelos aterros e alicerces do palácio de Nero, a princípio, e, depois, do palácio de Domiciano. Se, realmente, êsses adornos foram encontrados em tal lugar, deveriam ter sido aí abandonados cêrca do ano 100 antes da éra cristā. Repetimos que o descobrimento precisa ser verificado, é necessário ter-se certeza do local em que foram encontrados e dos lugares de que provieram tais ornamentos. Se êsse descobrimento se confirmar, apresentará a nosso espírito um maravilhoso objeto de fantasia. Nāo podemos ficar por demais surpreendidos. Os Ptolomeus mantinham relações regulares com a India. E muito possivel que o descobrimento das monções, que tanto facilitou o comércio através do Oceano f́ndico, date justamente de cêrca do ano 100. Atribui-se êsse descobrimento a Eudóxio de Cízico, que explorou o Oceano índico. Tentou, mais tarde, realizar o périplo da África, partindo do Atlântico. Seu nom. deve ser relembrado como o de um valente precursor de Vasco da Gama. Nada de admirar, portanto, se, pelo ano 100, alguns comerciantes atingiram a Indochina: Era, aliás, ao mesmo tempo que se abria uma rota comercial através da Ásia Central, entre a China e o Ocidente. A primeira caravana que os chineses enviaram rumo ao Ocidente, depois de haverem afugentado os hunos da terrà dos hérvios, data justamente do ano 106 antes de Cristo.

A casa dos grifos é assim chamada por causa de um belo adôrno de grifos esculpidos em baixo-relêvo, $\mathrm{O}$ país dos 'grifos, porém, é justamente a Sibéria, onde êsses monstros eram conside- 
rados como guardas do ouro. Ousariamos dizer que, mesmo na ornamentaçāo das paredes dessa casa, cremos reconhecer um estilo oriental? Eis-nos, pois, na casa de um dêsses ricos cavalheiros, capitalistas da época; tinha, talvez, capitāes que se divertiam trazendo-lhe jóias da Malásia; pena que Cícero tenha sido tāo pouco curioso por tudo que nāo fôsse a própria Roma. Ao invés de suas conversas filosóficas, pedantes, com Lúculo nos jardins de Baias, o que nāo dariamos para que êle nos tivesse narrado suas conversas na casa dos grifos com um comerciante que voltasse da Chiná... Seu hóspede ter-lhe-ia oferecido um colar melanésio para sua filha Túlia...

Novidade a respeito de Cícero é o que nos traz um livro de Carcopino; é escrito com um tom de ódio, contra o qual protestamos; acha o autor que a correspondencia de Cícero foi publicada por Otávio, com o fito de desonrá-lo, que Cícero foi vendido por Ático, seu melhor amigo, e por seu próprio filho. Essas teses extremas nāo serāo aceitas fàcilmente. Admitimos de boa mente a data de publicaçāo proposta por êsse autor, quatro anos antes da batalha de Ácio; somos, porém, levados a crer que Otávio quís honrar a memória de Cícero. Nessa admirável coleçāo, que constitui a mais sincera das confissões, é fácil encontrar armas contra os políticos de todos os partidos, tanto contra Pompeu como contra César e contra o próprio Cícero. E o panorama de tôda uma época pré-revolucionária que revive diante de nós.

Cícero nāo é um grande politico, e é pena. Nunca deixou de ser um burguês parvenu, que se exasperava com o desprêzo condescendente dos grandes que utilizavam o seu talento, que se distanciava do povo pelo horror à desordem, ficando demasiado aten10 aos interêsses das sociedades financeiras de que era advogado; na realidade, porém, tinha razāo em considerar como a obra-prima de sua vida o fato de ter realizado, por algum tempo, a aliança dos grandes senhores da finança. E essa aliança que Otávio conseguirá, um dia, revalidar; é nela que, por dois séculos, repousará a solidez do regime imperiai. É impossivel que Otávio nāo tenha sentido a intima afinidade de sua politica pessoal com as hesitantes e desastradas aspirações de Cícero.

Aproximamo-nos da época cristā. A velha religião pagā nāo nais bastava às almas piedosas. Suas festas eram, na maioria, ritos agrários; permitem acompanhar de mês a mês o crescimento da. espiga de trigo, as transferências dos rebanhos. Platāo fôra o profeta de um culto metafísico a que pertencia o porvir, e mesmo nas obras de Cicero, que tāo mal conhece Platāo e que, na realidade, permanece descrente e céptico, podem notar-se os progressos dessa religiāo filosófica.

Devia esta entrar em concorrência com a revelaçāo divina que se fêz na Galiléia. Gostariamos de assinalar um descobrimento que acaba de causar admiração a todos os que se preocupam com as: 
origens cristās. Descobriu-se recentemente na Palestina um tesouro de velhos livros escondidos numá gruta, no comềço da éra cristā. Nele se encontram os mais antigos manuscritos de certos livros do Velho Testamento. Decifrou-se, também, nele, um comentário das profecias de Habacuc(2). Ora, eis a que Dupont-Sommer reconstituiu, baseado nesse comentário: Jerusalém assistiu ao aparecimento de um filho de Deus, um Messias, que foi martirizado. Ele reapareceu pouco tempo depois, durante uma festa judàica, que coincidia com uma catástrofe. É preciso datar êsses surpreendentes acontecimentos; Dupont-Sommer data o suplicio do Messias de 65 antes da éra cristā; teria reaparecido em 62, quando, aproveitando-se de uma festa judaica, Pompeu tomou Jerusalém. A lembrança dêsse Messias teria sobrevivido na misteriosa seita dos essênios, êsses ascetas que viviam na meditação e na pobreza e entre os quais freqüentemente se reconheceram, de fato, os predecessores dos cristãos. Um Messias supliciado em Jerusalém exaramente 100 anos antes de Cristo. Se êsse descobrimento se confirmar, ficará bem evidente que a história das origens cristās terá novas luzes. E, antes de tudo, será muito difícil negar, como fêz James Frazer, a existência histórica do próprio Cristo.

Quanto à história do fim da República, as escavações arqueológicas poucas novidades trouxeram. Assinalamos a casa dos grifos, encontrada sob o Palácio Imperial. Quanto à própria Roma, pedimos escusas por aludir a um descobrimento um tanto ignóbil; nas escavações profundas do Forum, ao sul do Palatino e ainda em dois lugares, encontrou-se um estranho tipo de edificio, com corredores providos de cubiculos; as inscrições infames nāo permitem duvidar tratar-se dos lupanares de Roma.

Melhor é transportarmo-nos a Preneste. As destruições de guerra revelaram aos arqueólogos as partes altas do templo da Fortuna. O templo estendia-se por uma série de terraços nas encostas dos montes; era tāo vasto que o pequeno burgo de Palestrina aí se estabelece; mal se conheciam, porém, as disposições dos terraços superiores, as compridas rampas das procissões, os arranjos teatrais dos pórticos; a peregrinaçāo a Preneste fará com que reviva, em sua magnificência, um dos lugares mais sagrados do Lácio.

Seria, porém, injusto falar apenas de Roma e deixar no esquecimento os vencidos.

Roma impôs sua cultura e sua lingua a povos que possuiam, também, longa tradiçāo; esta, porém, foi interrompida ou momentâneamente sufocada. A arqueologia faz com que êsses povos oprimidos revivam para nós, e cada nação européia se preza de remontar a êsses longinquos antepassados.

(2). - Habacuc. um dos doze pequenos profetas Judeus; viveu entre 650 e 627 a. C. (Nota do tradutor). 
Queremos sòmente chamar a atenção para o interêsse das escavações da Gália meridional. Ai se exploram pequenas praças fortificadas, oppida, visitadas pelos primeiros colonos gregos. $\mathrm{O}$ conhecimento que temos das ruinas de Marselha foi renovado em conseqüência do brutal aniquilamento, exigido pelos alemáes, do Velho Pôrto. Reapareceu o pôrto grego e também o romano. É admirável encontrar de novo aqui, na cronologia das cerâmicas, essa mesma interrupção no $\mathrm{V}$ século que notamos na Itália Central. A Marselha do VI século, porém, como a Roma dos Tarquínios, devia ser uma cidade ativa e brilhante; ela reassumirá sua ctividade no IV século.

Gostariamos, sobretudo, de insistir na extrema importância dos descobrimentos feitos num oppidum situado pouco ao norte de Aix-en-Provence, Entremont, aparentemente capital do pequeno povo dos sályes. Reconheceu-se aí todo o traçado da muralha, o desenho das paredes e o plano das casas; tais construções datam aparentemente do II século antes de nossa éra. Mostram que êsse povo atingira alto grau de civilização. Principalmente, porém, encontrou-se um santuário ornado de grande número de estátuas de heróis, de pé ou agachadas; suas māos estāo postas em cima de cabecas cortadas cuja cabeleira acariciam docemente. $\mathrm{O}$ abominável rito da degolaçāo caracterizava o culto gaulês; os templos eram enfeitados com pilares sôbre os quais se esculpiam cabeças cortadas. Mostramos que uma categoria de gladiadores, que nāo se encontra na Gália, se constituia dos chamados trinqui, que eram, talvez, condenados à degola. As estranhas estátuas de Entremont, que são, atualmente, o orgulho do Museu de Aix, constituem um documento novo dêssè rito bárbaro; representam, aparentemente; chefes mortos, cujos dedos aspiravam màgicamente a vida que ainda reside nas cabeças cortadas. A série das estátuas foi bruscamente interrompida pela conquista romana, en 125 antes da éra cristā. Imitam, pelo estilo, as estátuas arcaicas. Cremos, de nosso lado, que as estátuas arcaicas de Marselha deviam ter sido, por muito tempo, os modelos de que se inspiravam os povos bárbaros. Em todo caso, Entremont, com seus muros, suas estátuas, revive para nós tal qual se erigia em sua alta colina, quando surgiram as legióes que Marselha chamara em seu socôrro.

A história de Roma, das órigens ao fim da República, foi transformada principalmente por causa da atençāo dada a três espécies de cogitações:

$\left.1 .^{\circ}\right)$ - Em primeiro lugar, a pesquisa das origens foi ligada às investigações da pré-história e de etnografia; lembremo-nos da surprêsa que tivemos ao folhear a. Introdução à História Romana de Modestov. Tratava-se nessa obra apenas de cacos, de fivelas, de ritos funerários; estamos, atualmente, habituados a êsse método. O problema dos indo-europeus passou para o primeiro plano de nossas preocupações. Os museus italianos de antiguidades, como 
os de Villa Giúlia, em Roma, e o de Florença, conservam religiosamente inúmeros vasos de estranho ou bárbaro perfil. Ainda näo conhecemos a verdade, é certo, porém, que a conheceremos. Esse mistério de nossas origens é importante para todos os que receberam por herança a civilizaçāo latina. Os primeiros indo-europeus que entraram na Itália eram pastores nômades: é preciso que - seu caminho seja reconstituido até a sua origem.

$\left.2 .^{\circ}\right)$ - Outro problema fundamental é o do imperialismo ronano; quais as fôrças que impeliram Roma à conquista do Império? Dedicamos vários cursos à pesquisa das causas das guerras de Roma. Recentemente, um sábio alemão, Gelzer, afirmava que o imperialismo romano tem origem religiosa: os romanos con* quistaram o universo por se terem convencido de sua missāo divina; os historiadores e os poetas da época de Augusto celebraram essa missāo. A nosso ver, porém, é uma interpretaçāo literária. Foram as fôrças econômicas que arrastaram Roma ao caminho dos combates. Essas fôrças nāo eram, naturalmente, no temjo dos pastores semi-nômades, as mesmas que no tempo dos capitalistas e banqueiros. Relacionar estreitamente a história econômica e a história politica constitui uma das tarefas fundamentais do historiador.

O problema consiste em saber-se em que condições a fôrça militar de Roma foi posta a serviço dos interêsses econômicos. E désse modo que se deve formular o problema. Nāo duvidemos de que a destruiçāo das grandes praças bancárias de Corinto e Cartago, no momento do apogeu, foi exigida pelos capitalistas de Roma; disso duvidar seria o mesmo que negar uma evidência.

$\left.3:^{\circ}\right)$ - A história religiosa, porém, exige atenção igualmente vigilante. E certo que os recentes trabalhos sôbre a evoluçāo do pensamento filosófico e religioso durante a República constitue:n contribuição de primeira ordem para a história das origens cristâs.

Como se explica a crise que liquidou o regime republicano? "Uma democracia nāo pode governar um Império", proclama certa fórmula mordaz de um livro muito bem feito de Ronald Syme. Dizem as cartas de Cicero, desde o ano 54 antes de nossa éra, que nāo há mais república, que se sente um odor de ditadura.

Nas negociaçö̀es ocultas que resultaram finalmente na fundaçāo do regime imperial, bem evidente é que o papel desempenhado pelos homens de negócios e banqueiros, como um Balbo, um Postúmio, foi decisivo, e que Augusto nāo foi, a princípio, mais que um testa-de-ferro.

A definiçāo do regime imperial sempre preocupou os historiadores de direito público. No tempo de Augusto, Roma nāo é mo- 
narquia, nāo é mais república. Entretanto, todos os órgāos republicanos continuam suas atividades, sendo, porém, o seu funcionamento paralizado pela vigilância dos príncipes. Para definir tal dualismo, Mommsen inventara o têrmo diarquia. Podemos dizer que o aparecimento dos regimes de tipo fascista muito contribuiu para se esclarecer o problema: revelaram-nos como e por que motivo um Protetor surgia e destruia as antigas instituições, que êle parecia defender; Otávio considerava-se um $d u x$, e o têrmo tornou-se para nós muito mais claro desde que vimos um Führer em açāo.

Os interessantes estudos dedicados nestes últimos anos à autoridade imperial inspiram-se, mais ou menos, e com razāo, nas observações de nossa história contemporânea; sobretudo, porém, a politica de Augusto e de seu continuador, Tibério, acaba de ser para nós admiràvelmente ilustrada por uma inscriçăo gravada em uma placa de bronze em Magliano, na Etrúria, e que chegou a nossas māos quase intacta. Trata-se nada menos do que da lei eleitoral, que nos revela como se elegiam os cônsules, no comêço do Império. Essa lei data da época de Tibério, mas permite reconstituir uma lei semelhante, que data do tempo de Augusto. Será necessário dizer-se que conhecemos muito mal todo o sistema eleitoral de Roma? Constitui isso uma das lacunas mais graves de nossa ciência. O descobrimento da referida placa é, pois, um gran: de acontecimento. Não foram ainda feitos, a seu respeito, numerosos estudos, e gostariamos simplesmente de mostrar o seu significado essencial. Augusto destinava sua sucessāa aos filhos de Agripa, os principes da juventude, Caio e Lúcio Césares, que êle adotara. Ambos morreram prematuramente. A fim de honrá-los, imaginou-se isto: os votos nas eleições romanas eram dados näo per capita, mas por secções. Augusto criou novas secções, em que sòmente votariam os senadores e os cavaleiros mais ricos. Por ocasiāo das eleições consulares, tais secções emitiam votos preliminares. A escolha que as mesmas fariam seria atribuida ao nome dos príncipes mortos: dir-se-ia: "Caio César vota por êste", "Lúcio César vota por aquêle". Mais tarde, Tibério, após a morte de Germânico, e, novamente, após a morte de Druso, criou também novas secções em nome dêles.

Ora, o voto emitido por um pequeno número de privilegiados, em nome dos principes, dava origem a uma lista de candidatos entre os quais os eleitores eram obrigados a escolher. De semeIhante mecanismo tudo ignorávamos: repetiamos que o povo continuara a eleger os magistrados até à morte de Augusto e que, nesse momento, Tibério fizera com que passasse para o Senado c direito de eleger os cônsules e os tribunos. Dizíamos ainda que as candidaturas oficiais, aliás, falseavam o exercício do voto.

Agora, porém, vemos, na realidade, como é que, desde a época de Augusto, no ano 5 de nossa éra, uma lei confiou a um grupo 
restrito uma espécie de direito de proposição, a que o nosso texto dá o nome de "destinação". Tais proposições preliminares limitävam estreitamente a liberdade de escolha pelo povo.

Os historiadores nāo terminaram o exame dêsse texto admirável que lhes acaba de ser revelado. Todo o mecanismo do voto, sorteio das seç̧ões, afixação do nome dos candidatos, disposiçấo dos cestos em que se depositavam as cédulas, fechamento dos ceslos antes da contagem dos votos, tôda essa organização nos é descrita, pela primeira vez, de modo extremamente minucioso.

Esse descobrimento permitiu mais uma vez a verificaçāo da estranha incúria de Tácito. Ao resumir o texto dos novos votos por ocasiāo da morte de Germânico, êle silenciou quanto aos artigos que modificavam as regras do voto. Em outra parte, dá, sôbre o regime eleitoral, uma indicaçāo breve e falsa. Êsse admirável artista é um historiador sem seriedade. Em todo caso, difícil é negar que Augusto haja inventado, sem dúvida alguma de acôrdo com Tibério, um modo audacioso de falsear o escrutinio. Raro é que os ditadores possam abster-se dêsse subterfúgio. Mas a lei eleitoral votada no ano 5 de nossa éra, por duas vêzes revista no reinado de Tibério, constitui extraordinária fraude.

Nāo insistiremos quanto à evoluçāo dêsse regime hipócrita, inventado por Augusto. Aos poucos, aumenta a participação dos provincianos no govêrno do império, ao passo que diminui a dos italianos. Nāo se pode deixar de mencionar as belas pesquisas dos sábios belgas Lambrechts e Laët sôbre a composiçăo do Senado. Mostraram êsses sábios que o grande progresso dos provincianos data da época de Trajano, que os italianos, entretanto, constituiam. durante o século dos Antoninos, pouco mais da metade do Senado, e que é apenas no tempo de Severo que os provincianos se tornam maioria.

Muitas páginas da história do regime imperial foram reconstituidas pelos descobrimentos de inscrições, papiros, fragmentos de vásos; citaremos apenas alguns exemplos. Os juristas ficaram comovidos e cativados pelo curioso descobrimento, feito em uma casa de Herculano, dos autos de um processo de liberdade. Certa mulher idosa, Calatória Têmis, reivindicava como sua liberta uma jovem que dizia chamar-se Petrônia Justa; segundo a velha senhora, Petrônia nascera de uma de suas escravas e ela a libertara; a jovem, porém, pretendia que sua māe já era liberta quando ela mesma nascera, e que, por conseguinte, ela nascera livre. Os documentos novamente encontrados fazem com que recuperemos as intimaçōes de comparecimento diante do pretor de Roma, bem como os testemunhos selados. "Sei que ela é livre", diz uma dessas testemunhas, "porque eu mesmo negociei com o marido de Calatória, a fim de que êle aceitasse o reembôlso das despesas que tivera com a alimentaçāo de Justa e entregasse a filha à mãe". 
"Sei que ela nasceu escrava", diz outra, "e que foi Calatória que a libertou".

O caso é, a meu ver, muito elaro. Justa foi abandonada pela māe e recolhida pela patroa desta, que a educou com ternura, mas como escrava; é o próprio tipo dos alumni. Ora, os filhos abandonados podiam ser indiferentemente recolhidos para serem adotados ou escravizados. Se eram escravizados, podiam mais tarde procurar provar que haviam nascido livres. E esta a história de Justa, e ofereceu-se aos que educaram a menina o reembôlso dos gastos de alimentaçāo. Na ausência, porém, de qualquer documento de estado civil, não era fácil provar que a māe de Justa ainda era escrava ao abandonar a criança. Nāo havia, sem dúvida, outro recurso senāo a contagem dos testemunhos. Nos documentos que nos restam, os testemunhos a favor da liberdade sāo os mais numerosos. Os sábios que, dia após dia, tiveram a emoçāo de reencontrar êsses autos, esperavam que um documento faria com que se conhecesse, finalmente, o julgamento; esta esperança, porém, nāo se concretizou.

Insistimos nesta historieta porque ela faz com que reviva para ròs uma curiosa página da história do mundo servil.

É preciso dar-se importância bem diferente aos documentos que nos permitem reconstituir a história agrária; à medida que conquistava o mundo, Roma cadastrava-o. É principalmente às fotografias aéreas que recorremos na época atual para restaurar o desenho das divisóes en quadrados traçadas no solo pelos agrimensores romanos. Recentemente reconheceu-se, na regiāo oriental da Tunísia, em espaços imensos, nāo sòmente a divisāo em quadrados, que cremos remontar ao tempo de Tibërio, como também, no interior dessas divisões, os limites das propriedades.

$\hat{E}$, porém, zo descobrimento que o Cônego Sautel acaba de fazer em Orange que deveremos a reconstituição do mais importante documento que da história agrária de Roma possuimos; perfurando o solo para instalar o cofre forte de um banco, pouco ao norte do famoso teatro, caíram os operários num verdadeiro "ninho de mármore"; tinha havido nesse local, no fim da época romana, um montāo de pedras em que se haviam acumulado os'fragmentos dos relevos que adornavam o teatro, pedaços de estátuas $e$, finalmente, em muito grande número, fragmentos de inscrições gravadas em pedras.

Ora, tais íragmentos pertencem a um cadastro-gigante que correspondia a tôda a superfície da colônia de Orange, fundada na época de Augusto. Mede, no mínimo, 8 metros de comprimento por 6 de largura. No interior da divisāo em quadrados, na qual cada parcela está rigorosamente numerada, foram traçados, bem grosseiramente, os rios, os aquedutos. Num dêsses fragmentos acreditamos reconhecer o Ródano. 
Finalmente, para cada parcela, o cadastro fixa com precisào a categoria das terras que ai se encontravam: terra dada aos veteranos, terra restituida aos antigos habitantes, terra pertencente à comuna de Orange. As terras da comuna são alugadas com escritura de arrendamento perpétuo, o cadastro indica as tarifas, variáveis conforme os lotes, e os nomes dós primeiros adjudicatários. E bem evidente que a finalidade do cadastro consiste justamente em fazer-se o inventário dâs terras comunais. Não é um documento de Estado. Devia ter sido gravado pelos empregados da comuna de Orange quando o imperador Domiciano entregou às colônias as terras que nāo haviam sido distribuidas quando da fundaçāo e que o imperador havią, provisòriamente, reservado para si.

Tal documento muita coisa nos revela sôbre as categorias de terras e as tarifas. Sobretudo, porém, esperamos poder localizá-lo devidamente. Temos que identificar os rios cujo curso está traçado. Um dia poderemos repor em seu devido lugar as fronteiras romanas, ver que influência exerceram sôbre a paisagem e saber se algumas delas permaneceram imutáveis através dos séculos. É claro, por exemplo, que o limite setentrional do departamento de aucluse, que era idêntico ao do Condado Venaissin, coincide com traços de fronteiras romanas.

Foi ainda a fotografia aérea que permitiu encontrar novamente, nas fronteiras da Síria, o vestígio de obras que nāo sāo percebidas pelas pessoas que estāo em terra. O R. P. Poidebard aplicou êsse método notàvelmente na reconstituiçāo da fronteira estratégica, o limes da Síria(3). Por mais de uma vez, descendo à terra, tinha êle dificuldade em encontrar de novo o vestígio do fortim que havia visto do alto. $O$ mesmo método foi empregado recentemente para o estudo da fronteira meridional da África romana. O belo livro intitulado "Fossatum Africae" (4) encerra uma série de surpreendentes fótografias e renova completamente a história dêsses confins africanos.

A fotografia aérea revela também o vestígio dos pés de oliveira de vastas plantações em regiões atualmente desertas.

A influência romana, porém, estendia-se para muito além das conquistas do Império. Os sábios escandinavos estabelecem metódica classificação dos objetos de bronze que eram exportados desde a Itália até ao norte da Europa.

Os descobrimentos mais surpreendentes foram feitos nos países do Oceano Indico. Não se ignorava que os romanos tinham comerciado com os tamuis da İndia e que tiveram, até, em Misore, na costa de Bengala, um templo de Augusto. Sabemos, porém,

(3). - Vide a obra de A. Poidebard. La trace de Rome dans le désert do Syrie, Paris. Paul Geuthner. 1934 (Nota do tradutor).

(4). - Jean Baradez. - Vue aerienne de l'organisation romaine dans le SudAlgerien. Fossatum Africae. Paris. Aux Éditions Arts et Métiers Graphiques. 1949 (Nota do tradutor). 
atualmente, que, perto de Pondichéry, em Virapatnam, pode-se reconhecer um estabelecimento romano. A cerâmica do tipo de Arezzo, que ai se encontra, data do século I de nossa éra. Curiosas instalações industriais parecem explicar-se pelo preparo das musselinas.

Mais longe ainda, perto de Saigon, em Oc-Eo, foi encontrada grande quantidade de sinetes de comerciantes. Provam os mesmos que a influência romana ainda perdurava nessas regióes, no inicio do Baixo-Império.

Até nas estepes da Ásia Central se reconhece a passagem dos comerciantes romanos ou de soldados prisioneiros. O que, porém, preocupa os sábios é, principalmente, o estudo da curiosa arte das estepes, que adota motivos babilônicos, estilizamos e os transmite aos povos germânicos, que deveriam, mais tarde, "introduzí-los no seio dos reinos bárbaros.

Vimos a história dêsse singular Messias que acaba de ser revelada e que morreu justamente cem anos antes de Cristo. É, porém, principalmente a história das origens cristās que gostariamos de elucidar. Nada há que acrescentar, por enquanto, aos documentos que retiveram, nestes últimos vinte anos, a atençčo dos erudítos, mas cuja crítica permanece enganosa.

Em um quarto de Herculano, acreditara-se que se havia encontrado na parede a impressāo de uma cruz e mesmo a presença de um genuflexório; tal miragem desvaneceu-se. Entretanto, de modo algum é impossivel que se descubra ter-se dado, no Ocidente, pelo ano 50, a chegada dos primeiros cristāos. Nenhum progresso, porém, foi feito por enquanto.

Continua, contudo, o interêsse em tôrno de curioso enigna, uma espécie de palavras cruzadas, que se encontra desde a Itália até ao Oriente: colocando-se as letras em certa ordem, lê-se Pater Noster e, nas duas extremidades dessa expressão, um $A$ e um $O$; dir-se-ia tratar-se de um enigma cristão. Ora, êsse enigma também se lê em colunas de Pompéia; segundo os sábios italianos, êle atesta a prisāo de cristāos em Pompéia antes da catástrofe do ano 79; Carcopino, porém, julga que foram gravados muito mais tarde por escavadores clandestinos, e esta hipótese parece-nos preferivel.

As escavações autorizadas pelo Santo Padre nos arredores do túmulo de São Pedro davam a esperança de se solucionarem problemas muito graves. Constantino tivera grande veneraçāo pelos apóstolos; dotara o túmulo de Pedro de uma armaçāo de bronze e uma cruz de ouro. No tempo das invasões sarracenas, a igreja fôra profanada. Quando se substituiu a basilica de Constantino pela Igreja de Bramante e Miguel Ångelo, não se tocou no confessionário, o túmulo permaneceu invisivel. No século XVII aconteceu que, tendo-se aberto uma brecha na parede do confessioná- 
rio, percebeu-se um objeto brilhante entre os escombros. Pediu-se ao papa Gregório XVI autorizaçāo para alargar-se a brecha; êle, porém, não a concedeu. Todos os peregrinos que percorreram êsse subterrâneo denominado Sagradas Grutas Vaticanas, que cercava o confessionário, desejavam conhecer o segrêdo escondido por essas brancas paredes. "Mas - escrevia Monsenhor Duchesne nāo me desagrada que restem no mundo lugares misteriosos".

Esse mistério nāo existe mais. Tendo um sábio arqueólogo cristāo, Monsenhor Wilpert, tido a imprudência de calcular o pêso do bronze de que Constantino teria revestido o túmulo, afirmava ser tal massa irremovivel; dizia que ela havia escapado às pilhagens dos sarracenos e que, por conseguinte, seria certamente encontrada de novo. As escavações foram dirigidas por Iosi, arqueólogo eminente, depois que o Santo Padre concedeu autorização. Em consequîencia dessas escavações, descobriu-se um cemitério pagão muito rico. Sob a nave de Sāo Pedro estendia-se uma verdadeira cidade dos mortos, com rtias, quartos" ricamente decorados. Mais tarde, à custa de trabalhos gigantescos, foi essa cidade coberta de espessos aterros. Parece lógico atribuir-se a Constantino êsse imenso trabalho de terraplenagem, feito com o fim de preparar o terreno de sua igreja. A inscriçāo funerária de uma dessas campas encerra uma passagem do testamento do morto, que determina que êle será enterrado perto do circo. Eis, pois, duplamente confirmada a tradiçāo cristã: o circo de Nero, em que Pedro foi supliciado, ficava muito perto daí; Pedro teria sido enterrado num dos quartos dessa cidade mortuária.

É claro que essa simples comprovaçào nāo nos satisfaz; o túmulo do apóstolo é que é preciso encontrar de novo. Um testemunho de cêrca do ano 200 diz que nessa data se erigia no Vaticano o "troféu" de São Pedro; compreende-se, sem que, entretanto, haja certeza nisso, que êsse nome significa túmulo. Em todo caso, a ata das escavações não está publicada e, se êsse silêncio se eternizar, a opinião pública tenderá a crer que Sāo Pedro nāo se acha lá, sob o magnífico edifício de Miguel Ângelo.

Os que desejam estar em comunhão com a lembrança de Pedro e Paulo devem ir à igreja de São Sebastiāo, perto das catacumbas. Debaixo dessa igreja, também, as escavaçốes fizeram com que fôssem novamente encontradas, ainda intactas, grandes câmaras funerárias. Acima dessas câmaras, porém, fôra instalada uma espécie de refeitório campestre, a triclia. Nas paredes, decoradas de flores e animais, há uma quantidade de inscrições grosseiramente gravadas, que mencionam os nomes dos peregrinos que ai foram fazer um refrigerium em honra de Pedro e Paulo; o refrigerium é uma oferenda destinada a refrescar o morto, sendo que a origem do rito é egípcia. Por que, porém, ir a êsse local festejar Pedro, morto e enterrado no Vaticano, e Paulo, morto e enterrado na estrada de Óstia? No IV século, uma inscriçāo do papa 
Dâmaso dava a seguinte explicaçāo: "foi aqui que os Santos outrora habitaram" - habitasse pritus. E compreendia o excelente arqueólogo Lanciani que nessa hospedaria Pedro e Paulo estaciounaram quando chegaram a Roma; outra explicaçāo obteve a maioria dos sufrágios: quando da perseguiçāo dos cristāos, no reinado de Valério, em 253, ter-se-ia levado para êsse lugar os corpos de Pedro e Paulo, a fim de serem abrigados. Miais tarde foram levados a seus túmulos. Bem romanesco parece ser tudo isso, e é preciso lembrarmo-nos de que as "invenções" das reliquias, como se diz, sempre deram pretexto a graves erros.

Se a história das origens cristās permanece envolta em mistério, a história do paganismo, em compensaçāo, fêz surpreendentes progressos. Absolutamente nāo mais consideramos o paganismo como um conjunto de cerimônias arcaicas e ridiculas; o paganismo foi renovado pelas especulações filosóficas, principalmente pela ação do platonismo. Os mitos absurdos foram considerados como símbolos de verdades metafisicas; destinavam-se a facilitar o acesso da verdade aos espíritos excessivamente materiais. Assim é que Cumont dedicou um livro à interpretaçāo das imagens dos sarcófagos, nelas encontrando novamente a história da alma e do seu destino. A representaçāo de raptos, particularmente, significa a elevaçāo das almas a Deus. Êsse paganismo purificado, aliás, tendia a um monoteísmo: em uma série de notáveis obras, ก R. P. H. Festugière mostrou perfeitamente quanto essa evoluçào do paganismo o aproximava do pensamento cristāo. (O Deus dos pagãos - escreve êle - parecia-se cada vez mais com o verdadeiro Deus). Assim, aconteceu que, no tempo de Constantino, os pagāos e os cristāos falavam quase que a mesma linguagem.

Foi, em suma, uma espécie de religiāo comum, espiritualista, de tendência monoteista, aquela que professavam os romanos cultos do tempo dos Antoninos. Ao se terem estudado as origens dessa religiāo comum, nunca é demais ressaltar o papel desempenhàdo por Platāo. Pitágoras, também, exerceu, sem dúvida, alguma açāo; todos conhecem essa Capela subterrânea, próxima aos vuros de Roma, que Carcopino denominou Basilica pitagórica; será, porém, mesmo uma basílica? Recentes descobrimentos fizeram com que se soubesse que certas câmaras funerárias podem ser dêsse tipo de basilica. Talvez se trate de um túmulo, do qual todo o conjunto de imagens se explique em funçāo de um simbolismo. É, aliás, provável que alguns pitagóricos, inclinados à magia negra, ai tenham invocado os mortos.

Essa filosofia pagā nāo deve ser considerada isenta de absurdos. Devenos ao R. P. Festugièré a publicaçāo dos livros herméticos, isto é, curiosos libelos que encerram uma revelaçāo atribuida ao deus Hermes, idêntico ao deus egipcio Thot. Neles se encontram, entre desatinos, visões de grandeza poética, mas essas obras sāo importantes, principalmente, por fazerem com que assistamos 
à vulgarização das nobres especulações de Platāo. Trata-se de diálogos entre amigos que têm nomes de deuses.

$\mathrm{O}$ Egito restituiu aos que examinam êsses difíceis textos coleções quase intactas; a princípio, foi a mala cheia de textos maniqueus, cuja publicaçāo bem longe está do término. Mui recentemente, descobriu-se uma coleção de livros gnósticos, pertencente a um pequeno cenáculo do Alto Egito. Êsses místicos um tantc loucos conseguiram pôr em segurança tôda uma coleção de livros gnósticos e herméticos. Não são rolos, mas já livros que se podem folhear, códices; a encadernação de couro está intacta, os caracteres, cuidados como os de um manuscrito medieval e, para admiraçāo dos historiadores, êsses livros dāo-nos, no III século de nossa éra, os primeiros exemplares da escrita copta. Êsses textos, semi-cristãos, semi-pagāos, constituem para a história das religiões documentos de inestimável valor.

Tal é, pois, a extraordinária fermentaçāo religiosa no seio do paganismo. Lidando com as relíquias de uma época selvagem, recusando-se a romper com uma santa tradiçāo, conseguiam os intelectuais pagāos realizar êsse milagre de constituir uma religiāo de dogmas sábios e nobres, que nāo era indigna de enfrentar, um dia, o combate contra o cristianisno, mas que, também, sem dúvida, teria podido unir-se a êle. O patético diálogo entre Símaco e Santo Ambrósio bem resume os têrmos do debate: "Pode-se chegar à verdade por mais de um caminho", dizia Símaco. "Só nós é que possuímos a verdade", dizia Santo Ambrósio.

As escavações arqueólógicas também não deixam de contribuir incessantemente com seus materiais. Permiti-nos volver o nosso pensamento para a França; há dois anos, o jovem arqueólogo Duval, nosso discípulo, dedica-se, mesmo em Paris, ao estudo das ruínas dêsse belo monumento romano em que se estabeleceu a casa dos abades de Cluny. O plano do edifício, agora inteiramente reconstituído, é, certamente, o das termas. Nāo se encontrou, infelizmente, nem moeda nem cerâmica de época romana. O problema da data do edifício, portanto, só poderá ser resolvido por comparações. Essas escavações forneceram, acessòriamente, a prova de que a París dos romanòs terminava nas encostas da colina de Santa Genoveva. Houve, na realidade, duas Paris distintas, a París céltica da Ilha e a París romana da colina, e a París romana era percorrida por ruas que se cruzavam perpendicularmente. Muito fácil seria encontrar de novo, na Paris atual da margem esquerda, as linhas diretrizes da París dos romanos. Nada mais surpreendente que a permanência da rua Saint-Jacques, que continuava pela estrada de Espanha.

Devemos, ainda, assinalar o interêsse em tôrno das escavações de Estrasburgo. N. Hatt prossegliiu as pesquisas de Robert Forrer; fixa com precisāo a história das destruições dessa cidade. mártir desde a Antiguidade, que foi, muitas vêzes, destruida pelos 
germanos. Pôde, mesmo, situar uma dessas catástrofes no tempo de Trajano, cujo nome de vencedor germânico se explica dêsse modo.

A França pode apresentar aos que se interessam pelo passado romano nāo mais apenas êsses monumentos suntuosos (o teatro de Orange, as arenas de Arles e de Nîmes), mas também pequenas cidades que ressuscitam, como Pompéia, em maravilhosas paisagens: Vaison, St. Rémy, ao pé dos Alpilles(5), St. Bertrand de Comminges, junto aos Pirineus.

Para quem quer julgar a história do Império, as perspectivas nāo sāo mais as mesmas que as do século passado. O "século de ouro" dos Antoninos pèrde o seu prestígio, a atenção concentra-se em tôrno do agitado periodo que se lhe seguiu, em tôrno das crises sociais, das convulsões 'do III século. O objetivo foi, talvez, mesmo ultrapassado. Nāo é justo depreciar a obra dos imperadores Antoninos. Já tivemos, em outro trabalho, a oportunidade de comparar, na história da escravidāo, a açāo dos Antoninos com a dos Severos. A primeira é muito mais generosa, mais audaz, mais fccunda; os burocratas dos Severos não acrescentaram muita coisa ao legado dos Antoninos.

E verdade, todavia, que a época dos Severos faz com que assistamos a uma revoluçāo. E o fim do Império romano como Estado colonial. Daí por diante nāo mais existem no Império cidadāos e súditos: todos sāo cidadãos. Já se disse que era a maneira pela "qual os "povos de côr" se desforraram de seus conquistadores e, ao mesmo tempo, uma tentativa de destruição dos grandes proprietários de bens de raiz. Outrora, ao simples soldado quase nāo era possivel ir além da' graduaçāo de centuriāo. Daí por diante, pode tornar-se general e até imperador, como Maximiano ou Diocleciano. Assistimos, então, a um esfôrço muito sincero no sentido de se socorrer aos pobres, ao desenvolvimento de uma verdadeira economia dirigida.

Essa revoluçāo sacudia os próprios alicerces do mundo antigo. Infelizmente, coincidia com violenta investida dos povos bárbaros em tôdas as fronteiras do Império. Investida que, sem dúvida, tinha uma origem no centro da Asia, onde se movimentavam os grandes povos nômades; tôdas as fronteiras do Império foram invadidas ao mesmo tempo; pôde crer-se que chegara o fim do mesmo.

A arqueologia faz com que revivam essas horas trágicas; todos conhecem essa pequena cidade de Doura, no rio Eufrates; ocupada, no reinado dos Severos pelos romanos, tomada pelos persas em 256, coberta, mais tarde, pelas areias. Com grande surprêsa, foram aí encontradas uma capela cristā e uma sinagoga ju-

(5). - Alpilles ofj Alpines, pequeno macico montanhoso de Bouches-du-Rhóne, na Provença (Nota do tradutox). 
daica, enfeitadas com estranhas pinturas que representam a catástrofe; e assiste-se, mesmo, aos episódios do cêrco; em galerias, debaixo dos muros esburacados, surpreende-se o corpo a corpo entre romanos e persas, encontram-se sôbre as ossadas essas armaduras que anunciam as da Idade Média. Todos os fortes do limes(6) capitularam quase que ao mesmo tempo e, ainda ai, assiste o arqueólogo às supremas batalhas.

Devemos aqui assinalar por que pacientes trabalhos foi fixada a história da moeda romana no decorrer da crise do III século. Possuimos, mesmo, atualmente, diagramas que nos mostram a vertiginosa alta dos preços.

O Império romano é, durante o III século, como que uma crisálida da qual todos os velhos órgäos se liquefazem, se dissolvem, para dar lugar aos órgāos de novo corpo; ao cabo dessa temível crise, surge a Roma do Baixo-Império.

Êsse Império cristāo do IV século foi, por muito tempo, considerado como época de decadência; parece-nos hoje época de admirável riqueza. É então que surgem edifícios de gôsto novo e audacioso, tal como devia ter sido em Constantinopla o da primeira igreja de Santa Sofia; o livro que se folheia substitui decididamente os grandes e incômodos rolos e trabalha-se piedosamente nas edições clássicas; o grande papa Dâmaso anuncia as páginas da Renascença; convida Sāo Jerônimo a redigir uma ediçāo crítica da Bíblia; aos poucos vai-se tornando o cristianismo uma religiăo de Estado; não é, porém, sem dificuldade que vence a resistência que lhe opõe o paganismo, nāo as milenárias superstições dos camponeses, mas a sábia teologia dos intelectuais fiéis ao pensamento de Platão; transforma-se a organizaçāo do trabalho, poderosas corporações põem-se a serviço do Estado, a escravidão nāo é abolida, mas esvai-se aos' poucos, 'diante de um proletariado livre de direito, mas hereditàriamente prêso à sua tarefa.

Merece especial atençāo o problema do triunfo oficial do cristianismo. Os cristãos detestavam o Império, que era a cidade do diabo; desejavam a sua destruiçāo; pudera"se, năo sem verossimilhança, fazer cair sôbre êles a suspeita de haverem tentado incendiar Roma; fugiam ao serviço militar, desaconselhavam'a instituição da família. Nāo podia o Império contar com êssés maus cidadãos. Proibiu, entretanto, o imperador Constantino que os cristãos fôssem perseguidos e convidou-os a participarem de seus conselhos.

Numerosos estudos foram dedicados ao reinado de Constantino; sāo de J. Vogt e de A. Alföldi os mais recentes. "Dir-se-ia, escreve Vogt, que essa cabeça colossal de Constantino, que surge tāo inquietadora na côrte do Palácio dos Conservadores, em Roma,

(6). - Fronteira militar (Nota do tradutor). 
continuará sendo, por muito tempo, a Esfinge da ciência histórica".

Ora concebem-no como homem ùnicamente inspirado pelo interêsse do Estado, ora como perfeito cristāo, capaz, até, de redigir preces e sermões. Obstinamo-nos, de nossa parte, em considerá-lo um espírito sincero, que procurava a verdade: devia ao pai uma espécie de culto monoteista do sol. Foi-lhe, porém, revelado um sinal misterioso, que êle pôs nos elmos, nas armas dos soldados, e que the assegurou a vitoria. Mais tarde, convenceram-no os padres de que êsse sinal era o de Cristo. Os atos do principe dāo uma impressāo de hesitaçāo, de constantes marchas e contra-marchas, mas um texto de Filóstrato, recentemente encontrado, afirma que Constantino era um homem de açāo, brutal e decidido. alternadamente leal e astuto, encantador e desumano. As discussões continuarāo, pois, năo isentas de paixão. Tôda a controvérsia, porém, está dominada pelos belos trabalhos de Henri Grégoire, que põe em dúvida a autenticidade de um texto essencial, "a vida de Constantino", conservado sob o nome de Eusébio.

O capítulo da psicologia do primeiro imperador cristāo continuará, por muito tempo, a apaixonar os historiadores e todos os que sonham com êsse assombroso golpe teatral pelo qual foi o Império sùbitamente entregue àquêles que tanto o haviam detestado e que tantos motivos tinham para detestá-lo.

Os sábios que se dedicaram a narrar a história do Baixo-Império por muito tempo se desviaram da cidade de Roma; a funda-dora do Império, a conquistadora do mundo năo era, na realidade mais que tuma cidade provinciana; nela se cruzavam, outrora, tôdas as rotas do Mediterrâneo; agora, era pela Itália setentrional que passava o grande tráfico. Os próprios imperadores tinham que afastar-se do seu caminho para irem até Roma.! Sabe-se de imperadores que nunca lá foram. O Senado, entretanto, continuava a reunir-se na sua grandiosa sala, que Diocleciano havia restaurado.

Para quem, atuaimente, visita Roma, uma das mais profundas emoções é a que se experimenta ao entrar-se na sala do Senado, que os sábios italianos acabam de desembaraçar das modificações por que passara ao transformar-se em uma igreja. Podemos pas. sear pela bela calçada de mármore incrustado que parece estar intacta, percorrer com a vista os nichos de quadros esculpidos, subir os degraus que, de cada lado do corredor central, suportavam os assentos dos senadores. Foi ai que o paganismo agonizante travou as suas últimas batalhas. Era hábito, ao se entrar no Senado, atirar-se um grāo de incenso ao fogo que ardia diante da estátua da Vitória. Tal rito causava indignaçāo áos cristāos. Santo Ambrósio exigiu que o fogo fôsse extinto. Foi a ocasiāo de uma batalha de eloquiência que se travou em Milăo, diante do imperador, entre Símaco e Santo Ambrósio, e êste último foi o vencedor. Tirou-se do Senado o altar colocado diante da estátua da Vitória e, 
mais tarde, a própria estátua; os pagãos, porém' puderam murmurar que, com a estátua, desaparecera a própria vitória.

Belos estudos de Alföldi fizeram com que revivessem para nós os senadores pagāos de Roma. Ousaram imprimir na moeda romana, cada ano, por ocasião dos votos de 3 de janeiro, efígies que celebravam o culto de Isis. Trocaram entre si medalhas comemorativas dos grandes acontecimentos da Roma pagā, êsses medalhões chamados "contorniatos", por causa do seu contôrno ornado de uma profunda linha, cujo segrêdo acaba de ser descoberto por Alföldi. Conhecemos os nomes dêsses grandes senhores, Sinaco, Pretextato, Flaviano, que, até o fim, defenderam o culto tradicional. Essa Roma pagā dos derradeiros dias teve sua grandeza, seu heroísmo. É inevitável que os cristāos a tenham perseguido com o seu ódio. De boa mente nós os acusariamos de haverem, por um lado; feito com que malograssem as negociações entre o bárbaro Alarico e a côrte de Ravena, e, por outro, de haverem impelido Alarico contra Roma; e foi a uma crịstā, Faltônia Proba, que uma tradiçāo acusou de lhe haver aberto a porta de Roma.

Se quisermos conhecer as casas dêsses grāotsenhores, teremos dificuldade em encontrá-las em Roma, mas as escavações de Óstia restituiram as suas luxuosas habitações, distribuidas de maneira encantadora e complicada, com perspectivas de arcadas, com fontes de cativante romantismo e tôdas diferentes das casas de Pompéia ou de Roma.

Qual a causa da ruína do Império? Gostariamos, talvez, ao finalizar, de meditar sôbre êsse grande problema a que se dedicaram muitos estudos recentes. Habitualmente, êle é resolvido pronunciando-se a palavra decadência. O Império ter-se-ia encaminhado lentamente para o túmulo. A palavra decadência, porém, é muito confusa. Querer-se-á com ela significar o empobrecimenio, a desmoralizaçāo, a degenerescência? 'Tôdas essas palavras encerram uma imagem e gostar-se-ia de substitui-las por consideracões mais realistas. Certo é que o Império não estava em decadência; assistimos, ao contrário, ao florescimento da arte, das letras e do pensamento religioso. A organizaçāo burocrática do Estado é sábia e complicada. As universidades atraíam multidões de jovens que se destinavam ao funcionalismo, o qual, via de regra, se iniciavá pela carreira de advogado.

Pode-se censurar a estrutura social do império, a concentraçāo de imensas riquezas em poucas māos, a miséria dos pobres, a enorme quantidade de mendigos. Essa miséria, porém, parece ser menos grave do que no Alto-Império, pois a Igreja remediou a situação por meio de asilos, o Estado, com distribuiçães de pão, com médicos gratuitos. A escravidāo é, aos poucos, substituída por novas formas de trabaho mais condizentes com a dignidade humana.

Pode-se censurar a desordem monetária, a volta à economia natural. Os próprios vencimentos dos funcionários são pagos em 
objetos naturais. Esse mal, porém, nāo era irreparável. E clarơ que o Império ainda dispunha de imenso estoque de ouro.

A crise religiosa é, sem dúvida, mais grave. O cristianismo solapou os alicerces do Império. Aliou-se aos inimigos de Roma, os coptas, no Egito, os bérberes na África do Norte, os povos dos planaltos da Ásia Menor. Depois, como os limites do cristianismo não coincidiam com os do Império, as conversões se fizeram entre os germanos, abissinios e mouros; os bárbaros deram hospitalidade aos cristãos durante as perseguições. Constantino iludiu-se se pensou que acabaria com as disputas religiosas convocando os cristāos ao poder. Nāo deixaram de dilacerar-se mùtuamente acêrca de problemas teológicos, que eram insolúveis. É certo que êsses conflitós ideológicos enfraqueceram gravemente o sentimento da pátria romana, favorecendo, no seio do Império, as revoltas das nacionalidades.

A causa direta da ruina do Império, porém, foi a invasāo. Era difícil resistir-se, ao mesmo tempo, em tôdas as fronteiras. As próprias causas da invasão são múltiplas; a pressāo exercia-se desde o centro da Ásia. Era nas estepes de Keroulene, era no Lob-Nor que se preparavam as tempestades que desabaram sôbre a Europa. Os hunos impeliam os alanos, que, por sua vez, impeliam os gôdos. Ora, o exército do Império havia-se tornado muito mediocre. Por que? Porque os jovens livres fugiam ao serviço militar e porque êste se tornara uma profissāo. Todo cidadāo deve ser soldado: temos a conviç̧ão de que esta máxima vigora ainda hoje. Não somente os cidadāos nāo eram mais soldados, como também os soldados dos romanos eram da mesma raça que seus escravos. Como os teriam protegido? Em defesa de Roma estavam os seus piores inimigos.

Escrevemos há pouco tempo: o Império nāo teve morte natural, foi assassinado; ao escrever, um exército alemāo, acampado em território francês assassinava a França. Mas é preciso reconhecer também os erros dos vencidos; onde estavam as corajosas legiōes de heróicos jovens que fundaram o Império?

Lembraram-nos por mais de uma vez que, em livro mais antigo, nós nos propuzemos a considerar como causa essencial da ruína do Império o deslocamento das vias comerciais. Daí por diante, a grande estrada do comércio é a rota Reno-Danúbió; nos seus arredores vāo surgindo as capitais do Império: Trèves, Milāo, Sofia, Bizâncio. O papel desempenhado por Roma terminara. Era nessa grande artéria Reno-Danúbio que devia constituir-se um novo império, que seria denorhinado Europa. Grandes imperadores com êle sonharam, Augusto, talvez, Marco Aurélio, Maximiano. As invasões bárbaras, porém, não permitiram a realização dessa grandiosa obra. Em última análise, a nosso ver, foi êsse deslocamento das vias de comércio que causou a ruina da Capital do Ocidente, Roma. Para Constantinopla, ao contrário, convergiam 
tôdas as rotas maritimas e terrestres que asseguravam a solidariedade dos países do Oriente.

Assim pereceu Rona; em 546, no tempo das guerras entre os gôdos'e os bizantinos, a cidade imensa permaneceu inteiramente vazia por várias semanas.

Mas sua obra era imperecivel; ela nos legou a lembrança de uma obra de justiça, de paz, de grandiosa beleza, tão perfeita quanto possa ser uma obra humana. Muito fêz para preparar a unidade do mundo. Agradeçamos a seus grandes homens por terem trabalhado, como êles mesmos diziam, para o bem do gênero humano.

As duas conferências que tivemos a honra de aqui apresentar corresponderiam ao nosso desêjo se corrigissem dois graves erros:

O primeiro é pensar-se que a História de Roma não apresenta mais interêsse para o nosso mundo contemporâneo; na realidade, a lembrança de Roma está ainda bem viva em nossa língua, nosso direito, nossa religiāo, nossas artes. E Roma fornece à Sociologia materiais muito úteis.

Consiste o segundo em imaginar-se que a História de Roma está escrita e não mais precisa que se trabalhe nela. Tendes visto que ela se renova todos os dias. Tendes percorrido uma grande oficina em plena atividade. Precisamos de trabalhadores, permiti-me esperar que nessa grande obra colaborará cada vez mais a ardorosa e bela juventude brasileira.

\section{ANDRE PIGANIOL}

Professor do Colégio de Franca 